\title{
Expressive Strength Reduction through the Use of Perception/Epistemic Verbs in First Person Singular Subject Reference in British English, Castilian Spanish and Galician
}

\author{
Natalia Villar Conde \\ University of Santiago \\ natvill@usc.es
}

\begin{abstract}
British English, Castilian Spanish and Galician are three geographically and genetically close linguistic codes, although they exhibit important pragmatic differences. This can be seen when examining degrees of expressive strength in the message; that is, the extent to which the speaker commits him/herself to the proposition expressed. Considering in particular one of the possible ways of avoiding commitment to the message, namely the employment of perception/epistemic verbs in first person singular, it can be seen that English speakers make extensive use of this device. This can be connected to the interest in the Anglo-Saxon culture in avoiding imposition of personal ideas. As a result of a similar interdependence of linguistic and cultural aspects, Galician speakers do not make use of such a resource, and Spanish occupies a middle position, with some use of the structure analysed. The analysis considers five types of discourse for each language, showing that the socio-cultural context in which speech production takes place is important for discursive style.
\end{abstract}

\section{Introduction}

As Hernández Sacristán (1999) points out, the location of linguistic expression in context implies certain difficulties for professionals (e. g. in translation or language didactics) as well as for speakers in general (e.g. in immigration). In order to understand human 
communication, then, it is essential to first define some of the co-text and cultural factors accompanying linguistic production.

One specific aspect that is not particularly considered by linguists in general is the possibility in the Anglo-Saxon culture of diminishing strength in the expression of ideas. From the very beginning it must remain clear that this is only a pilot-study. The main objective here is a thumbnail overview that discloses interesting aspects of expressive strength in the speech of three European languages. This proposal could serve as a starting point of sorts: a first insight into quite an ample subject that could subsequently be delved into in many different ways.

The idea of 'expressive strength' is understood here as the strength that a message bears when the speaker is completely committed to it; in other words, the forcefulness that characterises the idea expressed even when there is no explicit self-reference ("this is so"). In contrast, the occurrence of a perception/epistemic verb in first person singular subject reference takes a degree of universality away from the idea expressed; "I see/consider this is so" suggests that the fact that this is so is not plain fact or unquestionable truth, but rather that it is a personal idea that may not be shared by others. This alone - with no pretension whatsoever of exhaustively analysing every type of self-reference- is the scope of the present survey.

The relevant studies are not particularly extensive (cf. Section 2 below), but the cornerstone can be found in Wierzbicka (1991: Chapter 2). There, the author comments on the 'opinion-oriented' style of the English language. She maintains that this language tends to modulate ideas by inter alia, subordinating clauses with perceptual or epistemic verbs and first person singular subjects. She attributes this linguistic habit to the great value that Anglo-Saxon culture places on the philosophical principle of non-interference in others' affairs. This tendency is also compared to the expressive strength that characterises the way of expressing opinions in Polish. Three important issues arise from the relatively brief comments in this source: 1) the English trend to modulate ideas, thereby diminishing their expressive strength; 2 ) the interdependence of linguistic and socio-cultural elements; and 3 ) the relevance of the compare-and-contrast approach. The intention in this paper is to examine the first two issues through the compare-and-contrast approach referred to in the third question. In the case of this study, the languages providing for the cross-cultural perspective are Castilian Spanish and Galician.

At first glance, it might seem that the three linguistic codes under examination (British English, Castilian Spanish and Galician) share a great deal: their Indo-European origin is common to all three and their speech communities are localised in Western Europe. But the aforementioned problems arising from cross-cultural contact suggest contextual differences expected to become clearer when brought into focus through the present analysis. In order to lay down the foundations for this hypothesis, the following section considers relevant research works. 


\section{Survey of earlier research}

\subsection{Visual perception and conceptualisation in self-reference}

Figure 1.1 below presents a number of constructs that correspond to visual perception. In Langacker's words (1999: 204-205),

First is the viewer $(\mathrm{V})$, also describable as the subject of perception. At a given moment, the viewer faces in a particular direction, thus determining the maximal field of view (MF), i.e. everything observable given this orientation. This overall field of view has both a dimly perceived periphery, where the viewer is situated, and a center characterized by greater perceptual acuity. Using a theater metaphor, I refer to the center as the onsiage region (OS); this is the general locus of viewing attention and constitutes the area in which acuity renders focused observation possible. By shifting our gaze within this frame, we choose the specific target of viewing attention, the focus (F), also describable as the object of perception. The dashed arrow represents the perceptual relationship between the viewer and the focus (or more generally, between the viewer and everything within the maximal field of view). Additionally, any specific configuration assumed by these elements is termed a viewing arrangement.

Figure 1 (Langacker, 1999: 205)

1 Visual perception

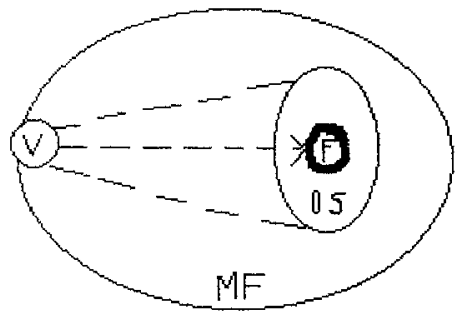

2 Conceptualisation

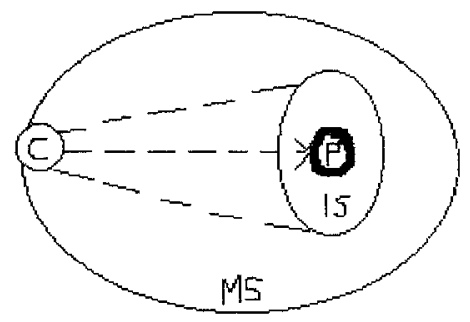

According to the author, this distribution of the elements that intervene in the process of visual perception is parallel to the group of constructs that explain the process of conceptualisation, which appears in Figure 1.2 (right side of Figure 1 above). Thus,

[t|hese perceptual notions are reasonably analyzed as special, even prototypical manifestations of corresponding conceptual notions... that are more abstract and broadly applicable. Corresponding to the viewer is the conceptualizer (C), or subject of conception. The maximal scope (MS) comprises the full content of a given conceptualization, not just central notions that we are specifically attending to, but also an array of more peripheral notions we may be only dimly aware of. The former constitute the immediate scope (IS), the conceptual analog of the onstage region. The specific focus of attention, the object of conception, is referred to here as the profile (P). The dashed arrow represents the construal relationship wherein the conceptualizer entertains the overall conception and structures it in a certain manner. Finally, 
any specific configuration assumed by these elements can be called a conceptual arrangement (Langacker, 1999: 205).

As reflected in Figure 1.1 above, the viewer is typically contained in the margin of the field of vision. This means that the viewer or perceptual subject does not usually occupy a central position in the perceptual process. The viewer can therefore have an extremely limited perception of him/herself. Thus,

$\mathrm{V}$ thus has only a vague and partial view of himself, at the periphery, if he sees himself at all. This viewing arrangement therefore maximizes the asymmetry between V's role as the subject of perception and F's role as the focused object of perception. To the extent that this aymmetry obtains, I say that V's role in the perceptual relationship is subjective, and that F's role is objective. (Langacker, 1999: 211).

Moreover, the author considers that every linguistic expression necessarily implies a constructive relationship between a conceptualiser and the corresponding conception, in the sense that language is a constructive process whereby the speaker (understood here as viewer or conceptualiser) gives linguistic form to ideas (understood here as visual objects or conceptions).

Speech production, then, is another process that is taken as parallel to visualisation and conceptualisation. In the three parallel processes, (linguistic process, visual process and conceptualisation process) the concepts of 'subject' and 'object' play a fundamental role:

In the usual arrangement..., the conceptualizer (i.e. the speaker) remains offstage and unmentioned, functioning primarily as the subject of conception, whereas the specific object of conception is by definition the expression's profile (the focal point within the immediate scope). To the extent that this asymmetry obtains, I say that the conceptualizer is construed subjectively, and the profile objectively (Langacker, 1999: 211).

All these remarks apply to prototypical situations (the canonical communicative situation, the typical situation in the process of vision, the prototypical conceptualisation model). Figure 1 above is thus a representation of a prototype. However, Langacker also indicates that the elements playing roles in the three parallel processes can be distributed differently. An alternative distribution would involve the prominence of the (grammatical/visual/conceptualisational) subject, which occurs when this element is not in the margin but in a more central position, becoming part of the object (though never ceasing to be a subject). In the author's words,

we can lessen the subject/object asymmetry by directing our gaze so as to put a portion of our own body onstage as the focus of attention. A conceptualizer can likewise go onstage as the profile (or focus of conception), as the speaker does in using the pronoun $I$. This yields an egocentric viewing arrangement in which -relative to the optimal arrangement of [Figure 1]the onstage region (OS) expands to encompass all or part of the viewer". 
This alternative distribution considerably lessens the assymetry on which the subjectivity/objectivity binomial is based. For instance, the occurrence of the first person singular subject pronoun in English, $I$, may be located in a middle point of a gradation as follows: the focalised element in the canonical case (external to speaker) is highly objective; the representation of the speaker through the pronoun $I$ is somewhere between objective and subjective; the implicit presence of the speaker in the message is highly subjective (with high subjectivity being equated to expressive strength and the complete commitment of the speaker to the message) (cf. Langacker, 1999: 389, n. 7).

It is important to note that the Spanish yo and the Galician $e u$-the corresponding versions of the first person singular subject pronoun- are tonic and optional in contrast to the English $I$, which tends to be unstressed and obligatory. But Spanish and Galician verb inflection provides for the subjective-objective intermediate position of the speaker through the verb ending (Spanish pienso, Galician penso). Thus, the three languages are able to reduce expressive strength through the use of a perception/epistemic verb in first person singular reference, whether this is done through a first person singular subject pronoun + predicator or through a predicator itself containing the first person singular subject reference. Different variants may be found for the three languages: for instance, the English dropping of the (normally obligatory) subject in rapid speech, or the emphatic inclusion of the (typically omitted) subject in Spanish or in Galician. In a more exhaustive analysis, the effects of this variability could be considered, but such an endeavour exceeds the scope of the present study; which, as indicated earlier, presumes to be an initial and general approach to strength diminution through self-reference in three European languages. Subsection 2.2 below surveys the scarce material concerning expressive strength reduction by any means whatsoever in English as compared to other linguistic codes.

\subsection{Expressive strength in English versus other languages}

As mentioned above, Wierzbicka (1991: Chapter 2) is the basic bibliographical reference on degrees of expressive strength in the Anglo-Saxon versus other cultures. She defines the English language as 'opinion-oriented'; or in other words, as oriented towards the modulation of ideas through - among other devices- authorial reference. Trying to avoid imposing a personal perspective on others, the Anglo-Saxon speaker seldom wants to present ideas to the listener as if they were irrefutable 'truth'. Behind this speech habit is a well-established democratic, liberal tradition according to which the generalised assumption of human beings' equality must be reflected in tolerance for differences.

The Anglo-Saxon opinion-oriented style is particularly reflected, precisely, in the expression of opinions. The expression of personal views tends to be cast in a linguistic mould signalling authorial reference (let us remember the parallelism Langacker noted in the communicative/visual/conceptualisation process). This modulation trend contrasts highly with the forcefulness of how opinions are usually expressed in Polish.

When a Polish speaker expresses a personal perspective and asks for confirmation, the word prawda 'truth' typically fulfills that function. The literal English equivalents sound 
quite strange (She is nice, right?, She is terrific, right?) (p. 42). On the other hand, the use of strength-diminishing introductory structures is frequent in English and scarce in Polish. In fact, some English examples even lack Polish equivalents altogether (e.g. the Australian English $I$ reckon or the American English I guess). Another contrast stems from the common use in English of rather, sort of and similar hedges in opinion and evaluation, again reflecting the principle of non-interference.

Wierzbicka refers her readers to Drazdauskiene (1981), another contrastive study signalling 'weak' opinion expression in English, with Lithuanian as the second term of comparison. The author states that expressions such as I think, I believe or I don't think are heard much more frequently in English than in Lithuanian.

Wierzbicka also refers to Geertz (1976), who notes another contrast between English and a different second term of comparison, Javanese. In this case, it is the Anglo-Saxon culture that appears as (relatively) 'strong', in contrast to the Javanese rejection of a forceful expression of personal views and feelings.

Geertz (1976: 238-241) - within a chapter entitled "The General Dimensions of Prijaji Belief" - signals the deep union in the Javanese philosophy of the concepts of 'feeling' and 'meaning'. In this particular cosmovision, feeling comprises touch, taste and emotion and is ultimately a way of understanding. Furthermore, this culture places great emphasis on exercising self-control with one's inner feelings. All this is determinant to the conversational subject matter, as illustrated by the following quotation from Geertz (1976: 240):

When Pak Ardjo (my landlord, whose house had been robbed in his absence) got back home after the robbery, he didn't say anything to Bu Ardjo about it for quite a while. In fact, when I came in, just after he returned, he was talking to a railroad friend and said there had been a lot going on here too, but he just ignored this and went on talking about other subjects... Later he told me he had resigned himself about the theft; had convinced himself by saying, 'If it's gone, it's gone, and that's all there is to it.' Being upset wouldn't bring the bike back, nor would getting angry at his wife.... He said be had kept himself from being upset about it all".

The Javanese cosmovision potentiates not only the omission of certain subject matters, but also a peculiar way of conveying ideas through strategies that show a linguistic and cultural overlap. When the Javanese speaker avoids to express what he/she thinks, the intention is that his/her true ideas and feelings do not bring about the listener's reaction during the course of the conversation. However, if the speaker expects something from the listener, in some way or other this must be communicated; otherwise, the risk that the speaker's expectations will go unfulfilled will be high. Geertz recalls two anecdotes in order to clarify how communication is made possible. The first anecdote is about a man who wanted to divorce his wife, but did not want to tell her so. He kindled an existing conflict between his wife and his mother until the former, unable to stand the situation any longer, asked for a divorce. The second anecdote is about a woman who wanted to convince her husband that they should move. She managed to make him find several written notes 
mentioning the uncomfortable state in which the family lived -notes that remained anonymous despite the man's desperate efforts to discover their origin. In the end, he took the initiative for them to move.

Another relevant study mentioned by Wierzbicka is Eades (1982). Again, the AngloSaxon culture appears as more direct than the second term of comparison, in this case the South-East Queensland Aboriginal society.

After extensive field work, Eades concludes that, in the context of the South-East Queensland Aboriginal society, information must be conveyed in the course of conversation, with strict limits on the use of questions. More specifically, informationseeking must begin with a statement related to the data sought, after which the speaker must wait until these answers spontaneously arise in the dialogue. Besides, the availability of information is determined by social stratification, with access to certain data restricted to certain social groups.

As regards information-seeking, then, the Anglo-Saxon culture would be the 'strong' term as compared to the South-East Queensland Aboriginal society. The former encourages the use of questions in all types of information-seeking situations, which results in the omnipresence of tests, questionnaires and interviews. In this sense, the questioning nature of Anglo-Saxon judicial processes poses a real problem for Aborigines. When involved, they find themselves in a completely strange situation and the experience tends to fail due to a lack of cooperation.

At this point, it seems quite clear that English cannot be considered direct or indirect, strong or weak, per se: it all depends on which language is the second point of comparison. Together with the relevance of the compare-and-contrast scope, it has also become clear that language and philosophical and socio-cultural aspects really are interwoven. The philosophical origin of pragmatics seems relevant in this regard. As Hernández Sacristán (1999: 19) explains, "si bien la pragmática como disciplina se constituye desde la lingüística y por los lingüistas, las piezas que la integran han sido configuradas, en su mayor parte, dentro del ámbito de la investigación lógico-filosófica". This philosophical origin is coherent with the significance of cosmovision in cross-cultural pragmatics, as suggested by the earlier research just surveyed (and by the present research as well). Therefore, it is convenient to review the philosophical principles that may support given linguistic strategies. This summary is presented in Subsection 2.3 below, concluding the survey of earlier research with a review of the relevant aspects in Hernández Sacristán (1999).

\subsection{Philosophical and socio-cultural values}

First of all, the author states that linguistic devices depend on cultural values. Furthermore, each cultural value is attributed a relative status depending on its position within the whole system of values. In this way, each value is defined through its relationship with the rest. More specifically, each basic cultural value is a member of a pair of opposite values, in such a way that, within a given particular culture, opposing values occupy opposing positions. The more valued a philosophical principle is, the less value is given to its opposite. A table 
(see Table 1) with basic oppositions is offered by the Spanish author in a partial reinterpretation of Wierzbicka (1991: 47 ff.), oppositions

...entre diferentes formas de entender la interacción social y de valorar las conductas lingüísticas que sirven de expresión a estas últimas. Nos permitimos hablar del conjunto de términos sometidos a contraste como principios en el sentido de que pueden considerarse fundamentos sobre los que se constituye el orden social: ninguno de ellos puede ser reducido a cero o imponerse a costa de otro de forma absoluta sin grave peligro de disgregación social o de quiebra de la imagen social del hombre.... (pp. 85-86).

Table 1. Opposite pairs of philosophical and cultural principles

\begin{tabular}{|l|c|l|}
\hline $\begin{array}{l}\text { Principio de no interferencia } \\
\text { Respeto a la autonomía del otro }\end{array}$ & & $\begin{array}{l}\text { Principio de solidaridad y } \\
\text { cordialidad }\end{array}$ \\
\hline Principio de ceremonialidad & - & Principio de autenticidad \\
\hline $\begin{array}{l}\text { Principio de mostración } \\
\text { pudorosa del "ego" }\end{array}$ & - & Principio de afectividad \\
\hline $\begin{array}{l}\text { Principio de relación fiduciaria } \\
\text { El hombre se debe a la norma }\end{array}$ & $\sim$ & $\begin{array}{l}\text { Principio de exculpación } \\
\text { La norma se debe al hombre }\end{array}$ \\
\hline
\end{tabular}

(Hernández Sacristán, 1999: 86)

The first opposite pair, 'non-interference' and 'respect for the other's autonomy' versus 'solidarity and cordiality', contrasts the rejection of becoming involved in others' affairs with the trend towards such an involvement. One culture in particular that places special value on the first member of this pair is the Anglo-Saxon culture (cf. the survey of Wierzbicka, 1991 above).

The second opposite pair is the 'ceremoniality principle' versus the 'authenticity principle'. The former reflects the ritualistic component always present, to a greater or lesser degree, in normal social interaction. The contrast is provided by the need felt by the participants of a social relationship for a feeling of authenticity. The 'fight' between these two opposites results in the victory of ceremoniality in the case of the Japanese culture, where a high value is attributed to non-interference. In contrast, however, ceremoniality also wins in the case of the Polish culture, where a high value is placed upon solidarity and cordiality (Wierzbicka, 1991). In essence, these pairs function independently, which implies a certain complexity in the value system: the relevance of one particular member of an opposite pair does not necessarily predict the relevance of either member of another pair.

As regards the third pair, 'veiled exposure of the ego' versus 'affection', the author indicates that socio-cultural values have an influence upon the linguistic expression of feelings, altogether removing some of these feelings from the linguistic production (let us remember the Javanese case) and shaping the linguistic mould of those that do get communicated. The author even suggests that, to a certain extent, cultural restrictions determine the way a people feels. 
The fourth pair, the 'fiduciary relationship principle' ('the human being must be referred to the norm') versus the 'exoneration principle' ('the norm must be referred to the human being'), corresponds to the degree of norm incidence, that is, to the community's higher or lower readiness to observe the rules and expect them to be observed; or, on the other hand, to the community's willingness to break them and excuse that they be broken.

Though such a set of values can be taken only as a sample, it is sufficient to illustrate the overlap of linguistic and socio-cultural patterns. Given the enormous relevance of this contextual aspect, the current subject matter must be checked against a context. To work with a context, language in practice must be the target. That is to say, a sample of language in use - a corpus-is needed. Section 3 below explains how the corpus for the present study has been selected.

\section{The corpus}

The corpus chosen is made up of 28,015 words. A first organisational parameter is language, in such a way that the corpus is divided into three large sections: English, Spanish and Galician. The English part contains 9,558 words; the Spanish part, 9,119; and the Galician part, 9,338. The texts represent contemporary usage (the time is the sixties, seventies and eighties for English and the nineties for Spanish and Galician, except for one particular Galician text from the seventies). Moreover, all of them are oral, as speech is the primary mode of language. All the texts are representative of standard language, which is achieved mainly through the important presence of language from the field of journalism. This latter characteristic responds to the interest that lies in analysing available resources in the linguistic code in general rather than in a specific geographical variety. And finally, the samples are all of adult language, as the target is not the language acquisition process but the actual usage of language after that process has been completed.

The main source for the English texts is the London-Lund Corpus of Spoken English (henceforward, LLC), a corpus contained in Hofland, Lindebjerg and Thunestvedt (1999). The LLC is a corpus of spoken language representative of the grammar employed by British English adult educated speakers. It is organised in different categories based on text type (monologue or dialogue, spontaneous or prepared speech and so on), totalling half a million words. For the present study, four samples have been taken from LLC. These have not been selected at random but have consciously been chosen so as to illustrate different degrees of formality in speech production. This criterion introduces the second organisational parameter in the corpus, which is discourse type (considering formality and many other content and formal aspects, $\mathrm{cf}$. at the end of the present section). Only one English sample comes from a different source: a radio news bulletin, a discourse type ruled out from the LLC on the grounds that it is language written to be spoken rather than spontaneous speech. Such a discourse type illustrates, however, the more formal extreme in the gradation of the speech analysed here. It has been included because, in principle, an analysis of the treatment applied by radio professionals to new information seems important in the study of 
expressive strength degrees. The source is also contained in Hofland, Lindebjerg and Thunestvedt (1999), and it is the prosodic version of the Spoken English Corpus (henceforward, SEC), which is as well a corpus of spoken British English, though this one does include radio news bulletins. The particular texts chosen (for the three languages considered) are explained below at the end of Section 3.

The English material is, then, the result of a conscious selection process, a rather frequent approach in pragmatic analysis. The Spanish and the Galician fragments take reference in the English samples.

With regard to Spanish, the texts are part of the Corpus Oral de Referencia del Español Contemporáneo, a database consisting of the computer transliteration of texts recorded on audio tapes from the oral register. This source can be found on the Internet, and the complete reference is cited in the table of authorities under Marcos Marín.

As regards Galician, most of the texts come from programmes broadcast on Radio Galega (the Galician public radio station) in November of 1999 and personally transcribed by me. The rest comes from Fernández Rei and Hermida Gulías (ed.)(1996) and VázquezMonxardín Fernández (ed.)(1997). These two publications consist of audio tape material and the corresponding transcriptions, though I retranscribed and adjusted the text selected from the latter so as to better fit it in with the rest of the corpus.

Extension restrictions explain why the complete corpus is not given here. However, all the examples considered are provided. The English examples provided here are not difficult to trace, since the lines are numbered according to the disposition of the texts in the two relevant corpora. The Spanish texts can be consulted on world wide web, and the examples refer to line numbers as they appear after printing the corresponding Internet pages. With regard to Galician, the references to lines correspond to the distribution of the texts in my personal compilation.

As suggested above, for each of the three language groups we have five subgroups divided by the context and the speaker-listener relationship. The first subgroup of the English group corresponds to the first subgroup of the Spanish group and to the first subgroup of the Galician group; the second subgroup is parallel in the three languages, and so on. Table 2 below outlines the corpus; the first five lines correspond to the five sets of subgroups, identifying the texts and providing in brackets the number of words for each; the last line provides the total number of words for each language group.

Also as suggested above, an increase in formality may be assumed from the first set (the set made up of the first subgroup in each of the three languages) to set five (the three fifth subgroups), according to the following schema:

set 1: informal conversation and everyday matters.

set 2: conversation combining the perspective of experts (more formal) with the perspective of people in the street (more informal); serious matters.

set 3: explanations of serious matters in an ideological or professional field, delivered in a didactic and more or less formal tone.

set 4: formal discourse by qualified speakers; serious matters. 
set 5: prepared discourse, oriented to provide information delivered by journalism professionals.

Table 2. The corpus

\begin{tabular}{|c|c|c|c|}
\hline & ENGLISH GROUP & SPANISH GROUP & GALICIAN GROUP \\
\hline $\begin{array}{c}\text { set } \\
1\end{array}$ & $\begin{array}{c}\mathrm{S} .2 .13258012 \mathrm{~B}-3620 ' \\
\text { and 'S.5.8 10-2650' (LLC) } \\
{[1,783 \text { words }]}\end{array}$ & $\begin{array}{l}\text { Corpus Conversacional in } \\
\text { "Ejemplos" in Section } 2 \text { of } \\
\text { "Laboratorio de Lingüistica } \\
\text { Informática: Corpus Oral" } \\
\text { in Marcos Marín [983] }\end{array}$ & $\begin{array}{c}\text { Teléfonos in "Miradoiro" } \\
\text { in Radio Galega up to line } \\
98 \text { and "Vacacións en } \\
\text { Ibiza" in Fernández Rei and } \\
\text { Hermida Gulías (ed.)(1996: } \\
\text { 130-132) [1,360] }\end{array}$ \\
\hline $\begin{array}{c}\text { set } \\
2\end{array}$ & $\begin{array}{l}\text { 'S.6.1b' and 'S.6.5 10- } \\
3220 \text { ' (LLC) }[2,649]\end{array}$ & $\begin{array}{c}\text { Corpus de Debate in } \\
\text { "Ejemplos" in Section } 2 \text { of } \\
\text { "Laboratorio de Lingüistica } \\
\text { Informática: Corpus Oral" } \\
\text { and sample Corpus } \\
\text { Cientifico up to line } 158 \text { in } \\
\text { "Laboratorio de Lingüística } \\
\text { Informática: Corpus Oral } \\
\text { del Castellano" in Marcos } \\
\text { Marín [3,113] } \\
\end{array}$ & $\begin{array}{l}\text { Queimaduras in } \\
\text { "Miradoiro" in Radio } \\
\text { Galega }[3,222]\end{array}$ \\
\hline $\begin{array}{c}\text { set } \\
3\end{array}$ & $\begin{array}{c}\text { 'S.6.9a 10-2100'; } \\
\text { 'S.10.8b'; and 'S.10.11a } \\
\text { 4060-4520' (LLC) }[1,268]\end{array}$ & $\begin{array}{c}\text { Sample Corpus de } \\
\text { Entrevistas in "Laboratorio } \\
\text { de Lingǘstica Informática: } \\
\text { Corpus Oral del } \\
\text { Castellano" in Marcos } \\
\text { Marín }[1,213]\end{array}$ & $\begin{array}{c}\text { "O traballo na Costa da } \\
\text { Morte", "A limpeza das } \\
\text { praias" and "A extinción de } \\
\text { incendios" in Fernández } \\
\text { Rei and Hermida Gulías } \\
\text { (ed.)(1996: 36, 113-115) } \\
{[1,682]} \\
\end{array}$ \\
\hline $\begin{array}{c}\text { set } \\
4\end{array}$ & $\begin{array}{l}\text { 'S.12.7 10-4970 1 1 a' } \\
\text { (LLC) }[2,912]\end{array}$ & $\begin{array}{c}\text { Sample Corpus } \\
\text { Humanístico in } \\
\text { "Laboratorio de Lingǘstica } \\
\text { Informática: Corpus Oral } \\
\text { del Castellano" in Marcos } \\
\text { Marín }[2,564]\end{array}$ & $\begin{array}{l}\text { Authors' explanations in } \\
\text { "Diario cultural" in Radio } \\
\text { Galega and 'Agora sufriu } \\
\text { un (...) positiva para el.' 'in } \\
\text { Vázquez-Monxardín } \\
\text { Fernández (ed.)(1997: 41- } \\
\text { 42) [2,216] } \\
\end{array}$ \\
\hline $\begin{array}{c}\text { set } \\
5\end{array}$ & 'secbpt03.02b' (SEC) [946] & $\begin{array}{c}\text { Sample Corpus de Noticias } \\
\text { in "Laboratorio de } \\
\text { Lingüistica Informática: } \\
\text { Corpus Oral del } \\
\text { Castellano" in Marcos } \\
\text { Marín }[1,246]\end{array}$ & $\begin{array}{c}\text { Noticias in Radio Galega } \\
{[858]}\end{array}$ \\
\hline $\begin{array}{c}\text { tota } \\
1\end{array}$ & 9,558 words & 9,119 words & 9,338 words \\
\hline
\end{tabular}


What follows explains the five sets of texts, bringing the present section to a close.

-Set 1. The English subgroup contains two texts. The first text is a face-to-face, spontaneous, surreptitiously recorded conversation. The second text is a private, nonsurreptitiously recorded conversation between equals. The subject matters are holidays and the like. The Spanish subgroup is a telephone conversation concerning daily matters such as a party. The Galician subgroup contains two texts. The first is an informal chat and the second is an interview about holidays.

-Set 2. The English subgroup is made up of two texts. Both are non-surreptitiously recorded conversations between disparate people. The first is an interview with a marketing expert. The second is an expert's psychoanalysis of a man suffering from problems in his marriage. The Spanish subgroup consists of a text in which several psychologists discuss their field and another text where several doctors participating in a television programme answer questions from the audience. The Galician subgroup deals with medical matters from the perspectives of a doctor, a patient, and people in the street.

-Set 3. The English subgroup contains three texts. The first is a non-surreptitiously recorded conversation between disparate subjects in which one person provides explanations on computers to another. The second is a scientific explanation on physics delivered in a didactic tone. The third is an explanation about vegetarianism. The Spanish subgroup is a text in which a flower-shop owner speaks about flower preservation. The Galician subgroup consists of three texts, each explaining a particular trade, namely fishing, beach cleaning and fire extinction.

-Set 4. The English subgroup is an institutional discourse on sexual censorship in art. The Spanish subgroup consists of two philologists' discussion of linguistic uses. The Galician subgroup contains several authors' discourses on art, language and culture.

-Set 5. The text is a news bulletin for each of the three subgroups.

\section{The variable}

The variable analysed must be delimited with precision. The following specific structure has been taken into account: first person singular reference (-optional- subject + predicator) for the focalisation of the speaker (actual or recovered through indirect speech) as a perceptual subject and of the perceptual process, in a subordinating clause (which may at the same time be subordinate). Prototypical examples would be the English (I) think/consider/believe/am sure/... [(that) subordinate clause] or (I) think/consider/believe/am sure... [nominal phraseto-infinitive clause] (e. g. I consider this to be the cause of the problem); the Spanish (yo) pienso/considero/creo/estoy seguro/... [(de) (que) subordinate clause]; and the Galician (eu) penso/considero/creo/estou seguro/... [(de) (que) subordinate clause]. 


\section{Examples}

The following examples of the variable have been found:

-In the first English subgroup: 11 examples ( 1 in the first text and 10 in the second). In the first text: "I'm sure Inspector Dunn will remove it for you" (11. 106-107); in the second text: "I think she is a lot happier" (1. 12), "I think they're going to Greece" (1. 67), "I thought well I I ought at least to know how to do that" (11. 91-92), "I felt [@] things were all right" (1. 95), "I think she's got quite a problem there" (11. 147-148), "I think she's got a problem" (1. 169), "I thought I'd do something fairly simple and warm and then we'll scarper off upstairs and and chat" (11. 177-181), "I suppose she [@] perhaps is used to fitting" (11. 234-235), "think it was before the second to last finals exam" (11. 254-255), "I think I believe in ghosts [i] in that way" (11. 302-304).

-In the first Spanish subgroup: 0 examples.

-In the first Galician subgroup: 3 examples ( 2 in the first text and 1 in the second). In the first text: "supoño que utilizarán en algún momento" (1. 21), "supoño qu'ó Gila meteranllo na caixa tamén" (1. 88). In the second text: "creo que estamos en todas partes" (11. 25-26).

Table 3.1 below illustrates the number of examples in the first subgroup for each language, the number of examples taken from each text, and, as the word length in the first three subgroups does not coincide, the normalised frequency for a text length of 10,000 words.

Table 3.1. Number of examples and normalised frequency in the first set

\begin{tabular}{|l|l|l|l|}
\hline & $\begin{array}{l}\text { FIRST ENGLISH } \\
\text { SUBGROUP }\end{array}$ & $\begin{array}{l}\text { FIRST SPANISH } \\
\text { SUBGROUP }\end{array}$ & $\begin{array}{l}\text { FIRST GALICIAN } \\
\text { SUBGROUP }\end{array}$ \\
\hline $\begin{array}{l}\text { NUMBER OF } \\
\text { EXAMPLES FOUND }\end{array}$ & $\begin{array}{l}11(1 \text { in the first text } \\
\text { and } 10 \text { in the second })\end{array}$ & 0 & $\begin{array}{l}3 \text { (2 in the first text } \\
\text { and } 1 \text { in the second })\end{array}$ \\
\hline $\begin{array}{l}\text { NORMALISED } \\
\text { FREQUENCY }\end{array}$ & 61.693 & - & 22.058 \\
\hline
\end{tabular}

-In the second English subgroup: 12 examples ( 2 in the first text and 10 in the second). In the first text: "I think that in this country [@]m we need both the [@]m underlying educational process [?@] the deeper more thorough study [?@] as well as [_dhi] drilling in current techniques [@] that I would [@?] see [?@] as being [dhi] training activity" (ll. 250261), "that I would [@?] see [?@] as being [dhi] training activity" (11. 259-261). In the second text: "I'm sure she may be right" (1.52), "I don't think in fact she would leave me" (1. 62), "I certainly don't think she would leave me" (11. 66-67), "I think she recognizes that" (1. 73), "I don't think that that's entirely true" (11. 235-236), "I think if our good relationship had carried on then my wife would have good reason to think that I was going to be closer to her in the future than I had been in the past" (11. 237-243), "it's impossible I think for anyone to lose a brother particularly in these circumstances" (11. 276-279), "I'm quite certain that when you'd heard he'd died there must have been a bit of you that have said I 
killed him" (1l. 295-299), "I think that's true" (1. 301), "I think now that you really ought to start mourning your brother" (11. 331-333).

-In the second Spanish subgroup: 5 examples ( 1 in the first text and 4 in the second). In the first text: "en el niño pequeño esta depresión yo pienso que se puede... de alguna manera evaluar básicamente a través de su expresión facial, su pérdida de apetito, su cambio de humor repentino" (11. 21-23). In the second text: "imagino que... los médicos que le han visto 1 habrán realizado un estudio... en este sentido, del aparato digestivo" (11. 1-2), "Yo creo que su caso, si se los han extirpao y el conocimiento histológico por parte del cirujano que... se lo ha hecho lo tiene y no le ha pedido ni que haga ningún otro gesto quirúrgico ni ningún otro tratamiento, debe de olvidarse usted del tema" (11. 51-53), "Si esto es así, considero que es correcta la intervención quirúrgica" (1. 93), "es una... pregunta, pienso yo, de una especialidad eh..." (1. 124).

-In the second Galician subgroup: 4 examples. "Eu creo que é o, pa min é o principal" (1. 33), "Penso que vamos, polo menos o que fai é quitarche a picazón do calor" (1. 78), "entendo que queima máis" (11. 111,113), "eu entendo que temos que estar aislados, que s temos que estar nunha habitación esterilizada" (11. 263-264).

Table 3.2 below outlines the relevant data for the second set.

Table 3,2. Number of examples and normalised frequency in the second set

\begin{tabular}{|l|l|l|l|}
\hline & $\begin{array}{l}\text { SECOND ENGLISH } \\
\text { SUBGROUP }\end{array}$ & $\begin{array}{l}\text { SECOND SPANISH } \\
\text { SUBGROUP }\end{array}$ & $\begin{array}{l}\text { SECOND GALICIAN } \\
\text { SUBGROUP }\end{array}$ \\
\hline $\begin{array}{l}\text { NUMBER OF } \\
\text { EXAMPLES FOUND }\end{array}$ & $\begin{array}{l}12 \text { and } 10 \text { in the fecond }) \\
\text { and text }\end{array}$ & $\begin{array}{l}5 \text { ( } 4 \text { in the first text } \\
\text { and } 1 \text { in the second })\end{array}$ & 4 (only one text) \\
\hline $\begin{array}{l}\text { NORMALISED } \\
\text { FREQUENCY }\end{array}$ & 45.300 & 16.061 & 12.414 \\
\hline
\end{tabular}

-In the third English subgroup: 4 examples ( 0 in the first text, 0 in the second and 4 in the third). In the third text: "I don't think there's any problem that [@] [?]a vegetarian diet doesn't provide you with enough energy" (11. 13-16), "the thought [?] fo coming home after a run to face a fatty greasy meat meal was one of the reasons $I$ think that helped turn us vegetarian" (11. 22-26), "I find [@m] with the runnier that [?]it does improve the appetite" (1l. 27-30), "I think most people are interested in what vegetarian food looks like and what it tastes like" (11. 40-42).

-In the third Spanish subgroup: 1 example. "creo que he llegado a una conclusión muy... muy efectiva y muy práctica" (1. 11).

In the third Galician subgroup: 0 examples.

Table 3.3 below outlines the relevant data for the third set. 
Table 3.3. Number of examples and normalised frequency in the third set

\begin{tabular}{|l|l|l|l|}
\hline & $\begin{array}{l}\text { THIRD ENGLISH } \\
\text { SUBGROUP }\end{array}$ & $\begin{array}{l}\text { THIRD SPANISH } \\
\text { SUBGROUP }\end{array}$ & $\begin{array}{l}\text { THIRD GALICIAN } \\
\text { SUBGROUP }\end{array}$ \\
\hline $\begin{array}{l}\text { NUMBER OF } \\
\text { EXAMPLES FOUND }\end{array}$ & $\begin{array}{l}\text { (0 in the first text, 0 } \\
\text { in the second and 4 in } \\
\text { the third) }\end{array}$ & 1 (only one text) & 0 \\
\hline $\begin{array}{l}\text { NORMALISED } \\
\text { FREQUENCY }\end{array}$ & 31.545 & 8.244 & - \\
\hline
\end{tabular}

-In the fourth English subgroup: 4 examples. "the ban on sexual spectacle foul language and so on falls I believe into this class" (11. 332-334), "the indirect harms commonly attributed to pornography fall I believe into four main classes" (11. 444-446), "I think it's now agreed that there are no dangers in the one act of selfabuse that tends to follow or even accompany the consumption of pornography" (11. 475-480), "suspect that my own attitude like that of everyone else is based on some romantic fantasy about the purity and innocence of childhood" (11. 648-651).

-In the fourth Spanish subgroup: 11 examples. "creo que son usos que debemos evitar, por esa manera cursi de pronunciar" (11. 11-12), "yo creo que es tiempo ya de dar paso a las dudas de nuestros seguidores" (1l. 39-40), "Yo creo que aún tenemos tiempo de comentar alguna más" (1. 71), "Yo creo que ahí, la elegancia nos debe llevar a rechazarlo de plano" (ll. 89-90), "También he oído, creo, "brida" "(ll. 119-120), "yo creo que no hay que buscar otra palabra en este caso" (1. 124), "Eso yo creo que es aparte" (1. 127), "Yo creo que un hijo mío eh... desde luego no se pondría esas cosas" (1. 129), "yo creo que... estamos en distintos grupos, con distintas normas, distintas ideas" (11. 130-131), "yo creo que un joven, a lo mejor, no dice que se va a poner un bolero" (1. 146), "yo creo que vamos a dejarlo aquí..." (1. 158).

-In the fourth Galician subgroup: 4 examples (4 in the first text and 0 in the second). In the first text: "eso creo que é o que nos mantén o corazón ea..., e a mente aberta e fresca" (1. 42), "nos últimos dez anos e... penso que fixen catro individuais nada máis" (11. 139140), "creo que é a... unha das características importantes sí é esa... especie de... e enfrentamento mui mui directo co, co espectador, desde o propio corpo, desde da propia presencia física do, do artista" (11. 246-248), "qu creo que é evidente" (11. 303-304).

Table 3.4 below outlines the relevant data for the fourth set.

Table 3.4. Number of examples and normalised frequency in the fourth set

\begin{tabular}{|l|l|l|l|}
\hline & $\begin{array}{l}\text { FOURTH ENGLISH } \\
\text { SUBGROUP }\end{array}$ & $\begin{array}{l}\text { FOURTH SPANISH } \\
\text { SUBGROUP }\end{array}$ & $\begin{array}{l}\text { FOURTH GALICIAN } \\
\text { SUBGROUP }\end{array}$ \\
\hline $\begin{array}{l}\text { NUMBER OF } \\
\text { EXAMPLES FOUND }\end{array}$ & 4 (only one text) & 11 (only one text) & $\begin{array}{l}4(4 \text { in the first text and } \\
0 \text { in the second) }\end{array}$ \\
\hline $\begin{array}{l}\text { NORMALISED } \\
\text { FREQUENCY }\end{array}$ & 13.736 & 42.901 & 18.050 \\
\hline
\end{tabular}


-In the fifth English subgroup: 0 examples.

-In the fifth Spanish subgroup: 0 examples.

-In the fifth Galician subgroup: 0 examples.

Table 3.5 below outlines the relevant data for the fifth set.

Table 3.5. Number of examples and normalised frequency in the fifth set

\begin{tabular}{|l|l|l|l|}
\hline & $\begin{array}{l}\text { FIFTH ENGLISH } \\
\text { SUBGROUP }\end{array}$ & $\begin{array}{l}\text { FIFTH SPANISH } \\
\text { SUBGROUP }\end{array}$ & $\begin{array}{l}\text { FIFTH GALICIAN } \\
\text { SUBGROUP }\end{array}$ \\
\hline $\begin{array}{l}\text { NUMBER OF } \\
\text { EXAMPLES FOUND }\end{array}$ & 0 & 0 & 0 \\
\hline $\begin{array}{l}\text { NORMALISED } \\
\text { FREQUENCY }\end{array}$ & - & - & - \\
\hline
\end{tabular}

The whole of the English group contains 31 examples (normalised frequency 32.433 ), the complete Spanish group, 17 (normalised frequency 18.642), and the complete Galician selection, $l 1$ (normalised frequency 11.779 ).

\section{Analysis}

Table 4 below presents the frequency of the variable in the whole corpus, including normalised frequency for a text length of 10,000 words. The first number is the number of examples, followed by the normalised frequency, which appears in parentheses.

Table 4. Number of examples and normalised frequency in the whole corpus

\begin{tabular}{|c|c|c|c|}
\hline & ENGLISH GROUP & SPANISH GROUP & GALICIAN GROUP \\
\hline FIRST SUBGROUP & $11(61.693)$ & 0 & $3(22.058)$ \\
\hline $\begin{array}{c}\text { SECOND } \\
\text { SUBGROUP }\end{array}$ & $12(45.300)$ & $5(16.061)$ & $4(12.414)$ \\
\hline THIRD SUBGROUP & $4(31.545)$ & $1(8.244)$ & 0 \\
\hline $\begin{array}{c}\text { FOURTH } \\
\text { SUBGROUP }\end{array}$ & $4(13.736)$ & $11(42.901)$ & $4(18.050)$ \\
\hline FIFTH SUBGROUP & 0 & 0 & 0 \\
\hline TOTAL & $31(32.433)$ & $17(18.642)$ & $11(11.779)$ \\
\hline
\end{tabular}

The normalised frequency for the English group - 32.433-is a large number reflecting the significance in English of modulating ideas by subordinating them to a 
perception/epistemic verb in first person singular subject reference. This high figure is coherent with the comments in Wierzbicka (1991) concerning the frequency of such subordinating clauses in English, particularly in comparison with Polish and Lithuanian. In the case of this study, the contrast is established with Spanish and Galician, because of their relatively low acceptance of the device: neither language reaches the number of twenty occurrences per 10,000 words.

Anglo-Saxon democracy, the tradition of freedom and the relevance of the principle of non-interference in others' affairs all explain, according to Wierzbicka (1991), the frequent incidence of the device. This conclusion is highly coherent with the fact that the history of the speech communities corresponding to Castilian Spanish and Galician has been marked by long periods of an absence of democracy and freedom, fortunately overcome nowadays. The solidarity principle, the counterpart of non-interference (cf. Subsection 2.3 above), seems to be favoured by the Spanish and the Galician cultures.

It is relevant to consider here as well the opposition of individualism versus collectivism. Jandt (1998: 214-215) explains that individualistic cultures do not tend to particularly take into account the concept of group action in their objectives, whilst collectivist cultures consider tackling their tasks fairly more collectively. Furthermore, an individualistic community has less interpersonal cohesion. Great Britain figures as a highly individualistic country on the list provided by the aforementioned reference. This is consistent with the British English speaker's readiness to individualise linguistic expression tracing it back to him/herself as a perceptual subject.

The opposite pair 'veiled exposure of ego' / 'affectivity' (cf. Subsection 2.3 above) seems relevant as well. There is a widely-known, not only popular idea, that defends the adequacy of Galician for poetry because of its highly emotive and affective qualities as a language. In fact, king Alfonso X el Sabio chose Galician for his poetry and Spanish for his prose; and based on the same principle, Emilia Pardo Bazán preferred Spanish for her narrative. Galician is thus opposed to Spanish in a cliché taking the latter language as more 'serious', appropriate for both fiction and essay prose. With regard to Galician, the cliché prevails, and some of the typical features attributed to the Galician culture (though perhaps especially from the perspective of other cultures) are features such as the constant use of the diminutive -iño not only to indicate size but also, and especially, as a linguistic device to show affection.

The numerical data show the Galician speaker as less interested in subordinating the idea expressed to the perceptual subject and process. In other words, the Galician speaker is the one that practices the least veiled self-exposure, as his/her role when conveying the message bears the strength implied in remaining frequently hidden behind it. The spontaneous expression of what one feels is somewhat less frequent in Spanish (nevertheless, it does not reach the level of 'seriousness' of English). However, a huge difference is not observed between Spanish and Galician, both bearing a marked contrast with the remarkable incidence of the variable in English. In fact, the affective value of the diminutive is signalled in Hernández Sacristán (1999: 88) as typical of Spanish versus English. 
English can be said to prefer a veiled self-exposure to affectivity. The favourite value in this case combines personal exposure with tact. The result is not that the speaker does not figure in the message, but quite on the contrary, that he/she appears out of discretion, to avoid imposing his/her inner feelings upon the hearer. This tendency receives a linguistic shape quite appropriately through self-reference in a subordinating clause: in this way, the speaker figures (I think), and is identified as the author of the generated idea, thus avoiding the expressive strength of the alternative version without subordination. Such an alternative is rejected by the corresponding culture as an affective imposition on the receiver.

The 61.693 normalised frequency in the first English subgroup points to the significance of the variable in the category of informal conversation in English. Both texts in this subgroup deal with daily matters - holidays, gossip, and so on-, constantly modulating the ideas presented through $I+$ perception/epistemic verb. Besides, there is a gradation from subgroup one to five, specifically a progressive reduction in the frequency of examples. Thus, the subordination of ideas to authorial reference putting focus on the speaker as a perceptual subject becomes less interesting the more formal the text becomes. It can be concluded that the English speaker has a greater tendency to avoid the justification of ideas as personally-generated the more qualified he/she considers him/herself in that subject matter; that is, the more (in)formed he/she is.

The second English subgroup exhibits a quite high frequency, $-45.300-$, fairly superior to the 31.545 of the third English subgroup. A slightly stronger descent occurs with the fourth English subgroup, with a frequency of 13.736. Important though this number may be, it is highly significant that an institutional discourse avoids the variable in this way. The author may be rejecting an excessive employment of this device in order to present ideas (in a more or less strong fashion) in a discourse geared to convince through formal and rigorous argumentation.

The total absence of the variable in the fifth English subgroup can be connected to an idea proposed by Wierzbicka (1991: 63): the Anglo-Saxon culture's view of information "as a free and public good". If information is characterised by freedom, no manipulation is assumed, and if it is considered as public, no room for privacy or personalisation is left. This theoretical premise is surely behind the practice of rejecting the variable in coherence with the immediate and definite character that news professionals freely and publicly transmit to their news, in such a way that the receivers might assume their unquestionable reliability.

The normalised frequency of the variable in the Spanish group is 18.642 , a relatively significant number, though quite far from the 32.433 in the English group. In this case there is no gradation from subgroup one to subgroup five, either ascending or descending.

In Spanish, no example of the variable is found in informal conversation (first subgroup) or the news (fifth subgroup). The medical-scientific language of the second Spanish subgroup presents a frequency slightly surpassing sixteen. The number, though important, is fairly distant from the 45.300 of the second English subgroup. The third Spanish subgroup presents a frequency surpassing eight occurrences, in a didactic text on a professional activity. The fourth Spanish subgroup surpasses by more than three times the 
frequency in the fourth English subgroup (almost forty three versus almost fourteen). The high incidence of the device in the fourth Spanish subgroup, both in absolute terms as well as relative to English, occurs in a text where some philologists criticise certain linguistic uses from a more or less prescriptivist perspective, while at the same time providing explanations for these same uses. A qualified speaker combining explanation, argumentation and criticism is then specially prone to focalise him/herself as a perceptual subject through a grammatical subject pronoun + predicator in Spanish, in a relatively weak form of expression in comparison with that variable in English.

The frequency in the Galician group is of almost twelve occurrences, quite far from the frequency in the Spanish group and very distant from the frequency in the English group.

The informal chat on everyday matters in Galician (first Galician subgroup) presents a frequency surpassing twenty, notably superior to the total absence of the variable in the first Spanish subgroup, though notably inferior to the more than sixty occurrences in the first English subgroup. The text dealing with a medical subject in informal as well as formal registers (second Galician subgroup) exhibits a frequency slightly surpassing twelve, which is somewhat inferior to its parallel in Spanish and much inferior to the corresponding sample in English. In broad terms, the situation for set two is repeated for set three, in the sense that Galician occupies the lowest position, fairly surpassed by Spanish and visibly surpassed by English, with the added peculiarity that Galician lacks a representation of the variable. Besides, for the three languages, each subgroup of set three -explanatory discourseshows a frequency quite inferior to the frequency exhibited by the subgroup of the corresponding language in set two - professional analysis of daily problems. The frequency of 18.050 in the fourth Galician subgroup is very inferior to the frequency of 42.901 in the fourth Spanish subgroup, whilst it surpasses the frequency of the fourth English subgroup by more than four points. That is, qualified English argumentative discourse appears again as comparatively restricted in the use of the variable. It is a comparative restriction in the sense that such a discourse type exhibits the second lowest frequency of the variable in the English group -surpassed only by the lack of examples in the radio news bulletin-, but also in the sense that the two other languages fairly surpass the frequency of the variable in that text type. The fifth Galician subgroup coincides with its parallels in the two other languages in the total absence of the variable.

The zero frequency in the news bulletin in the three languages seems an interesting coincidence. Freedom and publicity in information transmission had been invoked to explain the absence of the variable in that discourse type in English, in connection with the well-established tradition of democracy and freedom. However, such values have not been identified as particularly autochthonous in the Galician and Castilian Spanish domains, where the sociopolitical history of the last century can not be properly defined by stability and equality.

Two considerations could account for that coincidence. On the one hand, the discourse type involved has information as its (professional) object. Thus, no place for hesitation in the presentation of ideas is left. A person whose job it is to convey new information, to let what happens in the world be known, is expected to transmit the object of his/her profession 
'as it is', to bring it directly to the receivers. Objectivity would thus be identified as a typical feature of the news bulletin journalist's professional ethics in the three cultures involved. On the other hand, the Galician and Spanish cultures can be said to receive and exhibit a strong influence from the Anglo-Saxon monopoly on information (the English language domain on Internet is just one example), thus assuming originally English but subsequently 'authoctonous' values.

In broad terms, considering now all the linguistic material examined, English freely uses perception/epistemic verbs in first person singular subject reference to subordinate the idea expressed, thereby reducing expressive strength. Also in general, the formality of the text is inversely proportional to the incidence of the variable in this language. The maximum rejection of the resource in English speech occurs in the informative genre, determined by formality, liberty, publicity, objectivity and professionality.

Castilian Spanish resorts to the variable with a certain frequency, though globally, it does so somewhat less often than English. A remarkable level is reached in argumentative discourse, with relaxed conversation and journalistic information at the other extreme. Argumentation in Spanish seems then to require the inclusion of a great deal of selfreference, in contrast to English. In English argumentative discourse, formality seems to be more relevant than the philosophical principle of individualism, thus resulting in such a low incidence of the variable. In Spanish argumentative discourse, the cultural value placed on the strong expression of personal ideas and feelings, together with formality, are not enough to provide for a strong linguistic expression rather than the subordination of the idea expressed to authorial perceptual/epistemic reference. The absence of the variable in the news bulletins in Spanish as well as in English can be related to professional objectivity as well as to an echo of the Anglo-Saxon publicity value. Besides, were it not for the fourth subgroup (argumentative discourse), the frequency for the complete Spanish group would be extremely low, with informal conversation presenting zero frequency and with two subgroups not even reaching twenty each.

Galician makes some use of the variable, less than the use in Spanish and much less than the incidence in English. Rejection reaches its maximum with didactic explanations and the radio news bulletin. For this latter discourse type the comments just made for Spanish (objectivity, professionalism and an echo of Anglo-Saxon publicity) seem to hold true as well, though the whole Galician group is characterised by a lack of a marked preference for the variable. The maximum frequency (in informal chat) hardly surpasses twenty.

\section{Conclusion}

Through this first insight, it seems that expressive strength reduction depends greatly on factors such as speaker-listener relationships and discourse types, with co-text and context determining the inclusion or not of perceptual/epistemic self-reference to subordinate the idea expressed. The compare-and-contrast scope adopted here has targeted three different linguistic codes, which has helped understand the significance of a particular feature within 
a particular culture, as the incidence of the feature in and of itself may be seen in a new light when considered in the context of more ample philosophical, historical and socio-cultural connotations. Expressive strength reduction through the use of perception/epistemic verbs in first person singular subject reference appears to be potentiated in British English in direct response to the values of individualism, non-interference in others' affairs and veiled self-exposure, whilst such a linguistic device is not so reinforced in Spanish and in Galician, where the values of collectivism, solidarity and affectivity seem to have a greater influence. Formality seems to run parallel to the rejection of the variable in English, with professionalism similarly discarding the variable in the three languages. This preliminary approach must surely be checked through more profound studies, though it has undoubtedly signalled certain clues in discourse analysis.

\section{Works cited}

Eades, Diana (1982): "You Gotta Know How to Talk...: Information Seeking in South-East Queensland Aboriginal Society". Australian Journal of Linguistics 2(1): 61-82.

Fernández Rei, Francisco and Carme Hermida Gulías (ed.)(1996): A nosa fala: Bloques e áreas lingüisticas do galego. Santiago de Compostela: Arquivo Sonoro de Galicia (Consello da Cultura Galega).

Geertz, Clifford (1976): The Religion of Java. Chicago: Chicago University Press.

Hernández Sacristán, Carlos (1999): Culturasy acción comunicativa: Introducción a lapragmática intercultural. Barcelona: Octaedro.

Hofland, Knut, Anne Lindebjerg and Jørn Thunestvedt (1999): Icame Collection of English Language Corpora (CD-ROM). University of Bergen: The HIT Centre.

Jandt, Fred Edmund (1998): Intercultural Communication: An Introduction. Thousand Oaks: SAGE Publications.

Langacker, Ronald W. (1999): Grammar and Conceptualization. Berlin: Mouton de Gruyter.

Marcos Marín, Francisco (head of the research group): "Laboratorio de Lingüística Informática: Corpus Oral", <http://www.lllf.uam.es/corpus_lee.htm > .

"Laboratorio de Lingüística Informática: Corpus Oral del Castellano", $<$ http://www.lllf.uam.es/corpus.html > .

Vázquez-Monxardín Fernández, Alfonso (ed.)(1997): Homenaxe a Ánxel Fole: Día das Letras Galegas 1997. Santiago de Compostela: Arquivo Sonoro de Galicia (Consello da Cultura Galega).

Wierzbicka, Anna (1991): Cross-Cultural Pragmatics: The Semantics of Human Interaction. Berlin/New York: Mouton de Gruyter. 